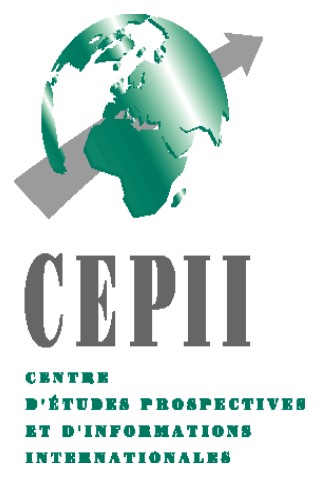

No $2006-18$
November

\title{
Vertical Production Networks: Evidence from France
}

Michel Fouquin, Laurence Nayman \& Laurent Wagner 


\title{
Vertical Production Networks: Evidence from France
}

\author{
Michel Fouquin, Laurence Nayman \& Laurent Wagner
}

This project is funded by the European Commission, Research Directorate General as part of the 6th Framework Programme, Priority 8,

"Policy Support and Anticipating Scientific and Technological Needs".

\author{
No $2006-18$ \\ November
}




\section{TABLE OF CONTENTS}

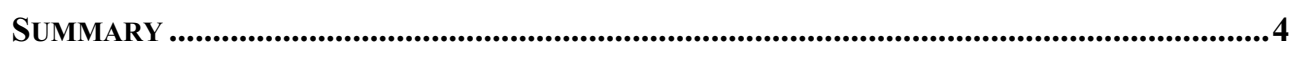

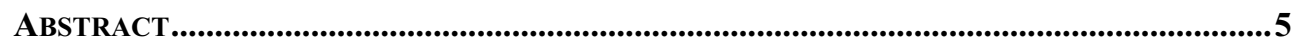

RÉSUMÉ ...............................................................................................................................6

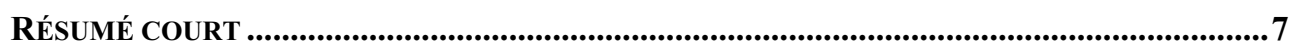

1. INTRODUCTION ..........................................................................................................................

1. Patterns of globalisation: A US-French Comparison........................................9

1.1. US multinationals: integrating world trade and production..................................10

1.2. French multinationals ................................................................................... 12

2. A MODEL OF VERTICAL INTEGRATION ...................................................................13

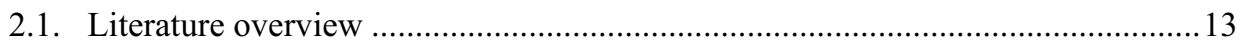

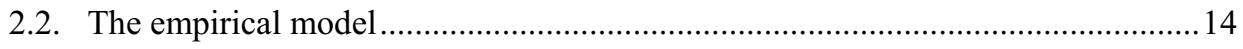

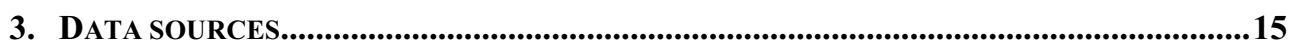

3.1. Surveys of parent companies and affiliates ....................................................... 15

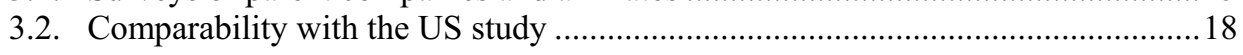

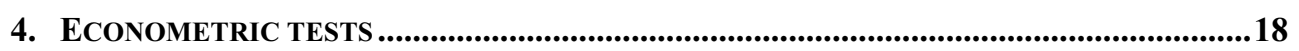

4.1. A common strategy that does not work …………..............................................18

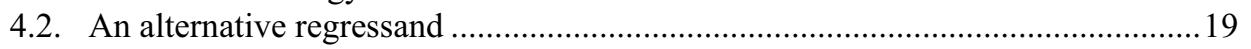

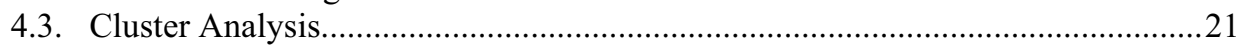

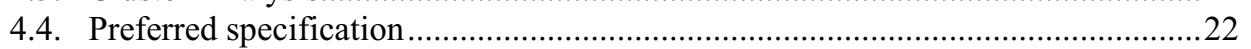

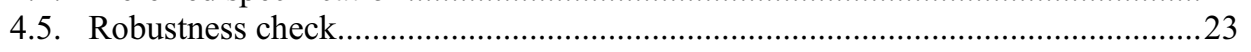

5. RESULTS ...........................................................................................................................25

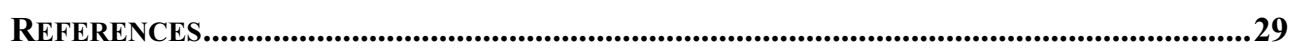

APPENDIX 1: DATA SOURCES AND DEFINITIONS ........................................................................31

APPENDIX 2: RELATIVE PRODUCTIVITY OF AFFILIATED COMPANIES

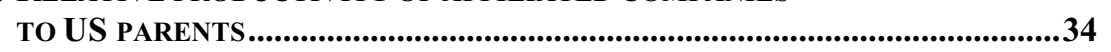

APPENDIX 3: THE HMS'S EMPIRICAL MODEL …............................................................35

LIST OF WORKING PAPERS RELEASED BY CEPII ..........................................................36 


\section{Vertical Production Networks: EVIDENCE From FranCE}

\section{SUMMARY}

A large share of international trade is under the control of MNCs and further, intra-firm trade has become a sizeable component of international trade. MNCs' motivation to proceed with FDI is twofold: market access and cost considerations. The market access strategy is believed to prevail in developed economies. In contrast, in developing markets, low local costs attract FDI in labour intensive segments of production.

This paper aims at identifying the determinants of vertical intra-firm production using data on French companies following the approach by Hanson, Mataloni and Slaughter (HMS, 2005). Our study distinguishes between developing and developed countries and the results provide evidence that the vertical specialisation of foreign affiliates depends on local conditions in their location. Indeed, wage and trade costs as well as a set of characteristics in the host country influence the share of intermediate products the affiliates import from their parents.

HMS found that higher wage and trade costs in the host country had a strong and negative impact on intra-firm flows of intermediate inputs. Similarly, in our study, lower wage and transportation costs, in the developing countries, increase, as expected, the vertical segmentation of production between French parent companies and their affiliates. However, when the affiliates are located in the developed countries, the parent firm scales up exports of intermediate products with the level of wages per employee and labour productivity. The latter being in excess of the former means a negative impact of unit labour costs on intrafirm trade in intermediate inputs. The results found by HMS with respect to American MNCs' higher exports of intermediate products in the wake of higher skilled-labour wages in the host country are then accounted for.

Subcontracting, economic freedom, and market potential are also important determinants of French MNCs' strategies. Outside EU-15, subcontracting to unrelated parties, and FDI seem to be close substitutes. Economic freedom in the host country matters. Like in HMS, results indicate a negative relationship between market potential, an indicator of market access, and $\mathrm{MNCs}^{6}$ exports of intermediate inputs to their affiliates.

We investigate further the horizontal component of intra-firm production networks. To do so, we separate out affiliates exporting back their production to France and affiliates that do not. Results for market potential substantiate then a mix of vertical and horizontal FDI. We check the sensitivity of our results by focussing on capital and labour intensive products. For the latter, market access seems to be the main motive behind MNCs' strategies. 


\begin{abstract}
This paper investigates the determinants of intra-firm trade of multinational firms located in France, using data on French companies. Results on the vertical pattern of production networks differ according to the affiliates' location. Lower wage and transportation costs in the developing countries increase, as expected, the vertical segmentation of production. In the developed countries, lower trade and unit wage costs, and hence, a strong and positive labour productivity matter a lot in explaining French MNCs' preferences. Among the other variables of interest, partnership and market potential have been given special attention. The results substantiate a mix of vertical and horizontal FDI, mainly when we separate out capital intensive from labour intensive intermediate products.
\end{abstract}

Classification JEL: F23, F1, L1.

Keywords: $\quad$ Multinational Firms, Intra-firm Trade, Intermediate Products, Vertical Production Networks, Horizontal FDI. 


\section{RESEAUX VERTICAUX DE PRODUCTION : LE CAS DE LA FRANCE}

\section{RESUME}

Une part importante du commerce international est constituée d'échanges entre maisons mères et filiales à l'étranger. Principalement, deux motifs sous-tendent les décisions liées à l'IDE : l'accès au marché (IDE horizontal) et les économies de coûts (IDE vertical). La stratégie d'accès au marché dominerait dans les pays les plus avancés. A l'inverse, dans les pays en développement, les faibles coûts locaux de production attireraient les IDE.

L'objectif de cet article est d'identifier les déterminants de la production verticale intrafirme à partir de données individuelles françaises en s'inspirant de l'approche développée par Hanson, Mataloni et Slaughter (2005). Dans notre étude, nous avons distingué pays développés et pays en développement. Les résultats montrent que la spécialisation verticale dépend des conditions du pays d'accueil de la filiale. En effet, les salaires et les coûts de transport ainsi que certaines caractéristiques du pays d'accueil influencent le montant des produits intermédiaires importés par la filiale en provenance de sa maison mère.

HMS ont montré que des salaires et des coûts de transaction (transport et droits de douane) élevés dans le pays d'accueil ont un impact fort et négatif sur les flux intra-firmes de produits intermédiaires. De même, dans notre étude, les niveaux plus faibles de salaires et de coûts de fret observés dans les pays les moins avancés favorisent la segmentation verticale intra-firme de la production. Néanmoins, lorsque les filiales sont implantées dans un pays développé, on observe une corrélation positive entre la part des échanges de biens intermédiaires et les niveaux de salaire par employé et de productivité du pays d'accueil. Le coefficient relatif à la productivité étant supérieur à celui du salaire, ce résultat implique un impact négatif des coûts salariaux unitaires du pays sur la part des échanges de produits intermédiaires. Ces résultats confirment ceux de HMS. Les multinationales américaines intensifient leurs échanges avec leurs filiales quand le travail disponible dans le pays d'accueil est plus qualifié.

La sous-traitance, la liberté économique et le potentiel de marché sont également des déterminants importants des stratégies des firmes multinationales françaises. En dehors de l'UE-15, la sous-traitance et les IDE sont substituables. La liberté économique du pays d'accueil compte également. De plus et comme pour HMS, nos résultats indiquent une relation négative entre le potentiel de marché, un indicateur d'accès au marché, et les échanges de produits intermédiaires au sein des multinationales.

Enfin, nous avons cherché à savoir ce que deviennent les biens assemblés par les filiales en éclatant notre échantillon selon que les filiales ré-exportent vers leurs maisons-mères ou non. Les tests confirment un mix de production intra-firme à la fois vertical et horizontal. Nous avons ensuite divisé notre échantillon entre produits intermédiaires intensifs en travail et en capital. Au moins pour les produits intensifs en travail, l'accès au marché guide la décision des multinationales françaises d'intensifier leurs échanges avec leurs filiales. 


\section{RESUME COURT}

L'objectif de cet article est d'identifier les déterminants du commerce intra-firme à partir de données individuelles françaises. Nos résultats illustrent la prépondérance d'un schéma de production verticale, qui diffère selon la localisation des filiales. Les estimations indiquent que les flux de produits intermédiaires entre maisons mères et filiales implantées dans des pays en développement sont d'autant plus importants que les salaires moyens du secteur manufacturier et les coûts de transport sont faibles. Pour ce qui est des filiales implantées dans les pays développés, ce sont les coûts de transaction (transport et droits de douane) et les coûts salariaux unitaires (salaires par employé sur productivité) qui sont les principaux déterminants du commerce intra-firme. De plus, nos résultats mettent en évidence une diversité dans la finalité de l'IDE. Au moins pour les produits intensifs en travail, l'accès au marché guide la décision des multinationales françaises d'intensifier leurs échanges avec leurs filiales.

Classement JEL : F23, F1, L1.

Mots Clés : $\quad$ Firmes multinationales, Commerce intra-firme, Produits intermédiaires, IDE vertical, IDE horizontal. 


\section{VERTICAL Production Networks: EVIDENCE From FranCE} Michel Fouquin, Laurence Nayman and Laurent Wagner

\section{INTRODUCTION}

The accelerating rate of firm globalisation is the result of both capital and service liberalisation in the form of an extensive right of establishment. In contrast to the manufacturing activities, foreign direct investment has generally been the main tool of globalisation for many service activities rather than direct trade.

Mundell's (1957) pioneering theory of the Trade-FDI nexus was based on the traditional Heckscher-Ohlin framework. He concluded that foreign investment might be a substitute for trade in countries that are less capital-intensive. However, facts tell a different story: the bulk of FDI occurs within developed countries, and FDI grows hand-in-hand with trade. Furthermore, it is usual to distinguish two types of FDI: horizontal, and vertical FDI. The former generally takes place within developed countries. Its prominent motive is market access, which may be achieved through mergers and acquisitions. Conversely, vertical FDI consists in relocating activities in low-wage countries, to benefit from low production costs, giving rise to the fragmentation of production processes.

With the development of FDI, not only a large part of trade is under the control of multinational firms, but also intra-firm trade for further processing becomes a sizeable share of multinational trade. In this case, direct investment is the source of new exports of final products by affiliates located in developing countries to developed markets, and of exports of intermediate products or inputs by parent companies to their affiliates. This is notably the case for most foreign investment in China (Gaulier, Lemoine, Ünal-Kesenci, 2005). This stylised fact is also described as the dominant Japanese strategy in Asia.

Hanson, Mataloni \& Slaughter ${ }^{2}(2001,2005)$ reconcile the approach on vertical production networks with the previous empirical research (Carr, Markusen, Maskus, 2001; Brainard, 1997), which demonstrates, with aggregate data, that higher host-country trade and wage costs foster horizontal FDI. In contrast, focusing on firm-level data on intermediate inputs for further processing allows HMS to study the composition of the affiliate output in

\footnotetext{
${ }^{1}$ M. Fouquin is Deputy Director (michel.fouquin@cepii.fr), L. Nayman is economist (laurence.nayman@cepii.fr) \& L. Wagner is research assistant (laurent.wagner@cepii.fr) at CEPII. Acknowledgements: we are grateful to SESSI, INSEE, DGTPE, BEA, the EUKLEMS network, CNIS and CEPII to have provided us with data; to Raymond Mataloni, Gordon Hanson, Agnès Bénassy-Quéré, Richard Baldwin, André Sapir, Olivier Blanchard, Eric Bartelsmann, Isabelle Bensidoun, Guillaume Gaulier, Cyrille Schwellnus and Hervé Boulhol for their support and useful comments. HMS hereafter.
} 
imported inputs or non imported ones (vertical vs. horizontal FDI) according to local market conditions.

More specifically, HMS show that vertical FDI is responsive to trade and wage costs and also to some policy characteristics. For example, a $1 \%$ fall in input prices linked to a reduction in trade costs brings about a 3.3\% increase in the demand of affiliates for intermediate inputs for further processing. Similarly, imported input demand increases by about $1 / 3 \%$ in the wake of a $1 \%$ increase in more-skilled wages. Estimates are also sensitive to policy characteristics such as corporate tax rates (-), the presence of an export processing zone $(+)$, the host-market size $(-)$, or the level of economic freedom $(+)$.

The results obtained by HMS (2005) on the determinants of intra-firm trade in intermediate inputs suggest that vertical integration should be investigated further by using other evidence than from the United States, for instance data from an integrated area such as the European union. We therefore explore the determinants of exports between French parent companies and their affiliates abroad, based on firm-level data. The results found by HMS in their 2005 paper provide a benchmark for our own findings about the vertical division of labour in manufacturing multinationals.

Section 1 outlines the stylised facts about US and French multinationals by comparing statistics related to their exporting activities. In Section 2, the empirical model is described. The share of total intermediate products in the affiliate's turnover is regressed on wage and trade costs, so as to characterise vertical integration, and also on some variables such as market potential, in order to test further for a horizontal component of FDI. Affiliate output can be produced by an integrated plant and be sold locally in order to take advantage of a large local market. In addition, we investigate whether the parent company maintains a special relationship with unrelated parties (outsourcing), along with being close to its affiliates. Section 3 describes the French databases we used and the main issues that arise from merging them into a consistent framework. Section 4 unwinds the econometric strategy that is different from the one used by HMS in the face of dissimilar data. Section 5 presents the results and Section 6 concludes.

\section{PATTERNS OF GLOBALISATION: A US-FrenCH COMPARISON}

Multinational corporations are major actors of globalisation: MNCs, which are generally large companies, dominate world industries and international trade, notably through integrated systems of production and distribution, bypassing traditional barriers to trade.

In the US, studies on multinationals use data from mandated annual surveys conducted by the Bureau of Economic Analysis. Data on US parent companies and their affiliates abroad are readily available in the same survey. In contrast, in France, two surveys providing both

\footnotetext{
${ }^{3}$ They assume that the scale of affiliate operations is given. Higher trade and wage costs lead to a decrease in imported inputs for further processing, and hence, to an increase in domestically produced inputs used by the foreign affiliate of the US parent company.
} 
kinds of information are called upon: one including detailed items on parent companies in France for the year 1999, devised by the SESSI, depending on the Ministry of Industry, and another annual one from the Ministry of Economics and Finance on affiliates of French parent companies.

\subsection{US multinationals: integrating world trade and production}

Table 1 shows that intra-firm trade, as measured by trade performed by US exporting companies with their related parties, amounts to about $35 \%$ of total trade, this proportion being quite stable between 1996 and 2003. The export share of large companies (more than 500 employees) in total exports increased from $69 \%$ to $73 \%$ during the same period.

Table 1: US Exporting Companies

\begin{tabular}{lllll}
\hline \multicolumn{1}{c}{ Total Economy } & \multicolumn{1}{c}{$\mathbf{1 9 9 6}$} & \multicolumn{1}{c}{$\mathbf{1 9 9 9}$} & \multicolumn{1}{c}{$\mathbf{2 0 0 3}$} \\
\hline 1 & Exporting companies identified, units (1) & 189,672 & 231,259 & 225,190 \\
2 & US total exports in US \$ billion & 625.1 & 695.8 & 724.8 \\
3 & US exports of identified companies in US \$ billion & 500.7 & 584.7 & 629.7 \\
4 & US exports to related companies in US \$ billion & 172.2 & 205.2 & 218.9 \\
5 & Share of US exports to related companies & $34.3 \%$ & $35.1 \%$ & $34.8 \%$ \\
6 & Large exporting companies (+500 employees), units & 6,953 & 7,739 & 6,808 \\
7 & US exports of large companies in US \$ billion & 344.8 & 416 & 458.3 \\
8 & Share in total exports (7/3) & $68.9 \%$ & $71.1 \%$ & $72.8 \%$ \\
& Manufacturing Companies (2) & & & \\
9 & Exporting companies, units & 61,665 & 65,795 & 64,791 \\
10 & Exports of companies in US \$ billion & 339.9 & 407.2 & 427.2 \\
11 & Share in total exports (10/3) & $67.8 \%$ & $69.6 \%$ & $67.8 \%$ \\
12 & Exports to related Companies, in US \$ billion & 135.9 & 159.0 & 162.3 \\
13 & Share of intra-firm (12/10) & $40.0 \%$ & $39.0 \%$ & $38.0 \%$ \\
14 & Large exporting companies, units & 3,719 & 3,509 & 2,952 \\
15 & Exports by large Companies, in US \$ billion & 291.5 & 349.7 & 364.9 \\
16 & Share of large companies in total exports (15/10) & $85.7 \%$ & $85.5 \%$ & $85.4 \%$ \\
17 & Of which to related parties, in US \$ billion & 126.8 & 148.8 & 151.5 \\
18 & Share of large companies in total exports to related & $93.3 \%$ & $93.6 \%$ & $93.3 \%$ \\
& companies (17/12) & & & \\
19 & Share of intra-firm exports in total large companies exports & $43.5 \%$ & $42.6 \%$ & $41.5 \%$ \\
& (17/15) & & & \\
20 & Share of large companies intra-firm exports in total manuf. & $37.3 \%$ & $36.5 \%$ & $35.5 \%$ \\
& exp. (17/10) & & & \\
\hline & & & & \\
\hline
\end{tabular}

Source: A Profile of US Exporting Companies 1996-1997, 1998-1999 and 2002-2003, US Department of Commerce, Census Bureau, Foreign Trade Division.

Notes:

$1 /$ Data are about who the exporter is but not about the nature of the exported product. In US exports, $92 \%$ are accounted for by manufactured products but only $68 \%$ of exports are exported by manufacturers. 2/ Representativity: $16.4 \%$ of exports came from unidentified companies in 1996, 12.5\% in 1999, 10.7\% in 2003 . 
Export flows stemming from the manufacturing MNCs make up more than $68 \%$ of total exports (including all exporting companies). For the manufacturing sector, $93 \%$ of intrafirm export flows originate from large companies. This indicates that large companies do not mediate their export flows through trading companies.

Furthermore, exports of manufactured products for further processing by US parent companies to their Majority Owned Foreign Affiliates (MOFAs) represent around 15\% of all US exports, $25 \%$ of total US parent exports and around $65 \%$ of US parent exports to their foreign affiliates (and 93\% to their manufacturing affiliates (BEA, 2002)). Indeed, this amount grew from $39.3 \%$ in 1966 to $64.7 \%$ in 1999 as shown in Figure 1 (Borga and Zeile 2004).

Figure 1: Share of US exports for further processing

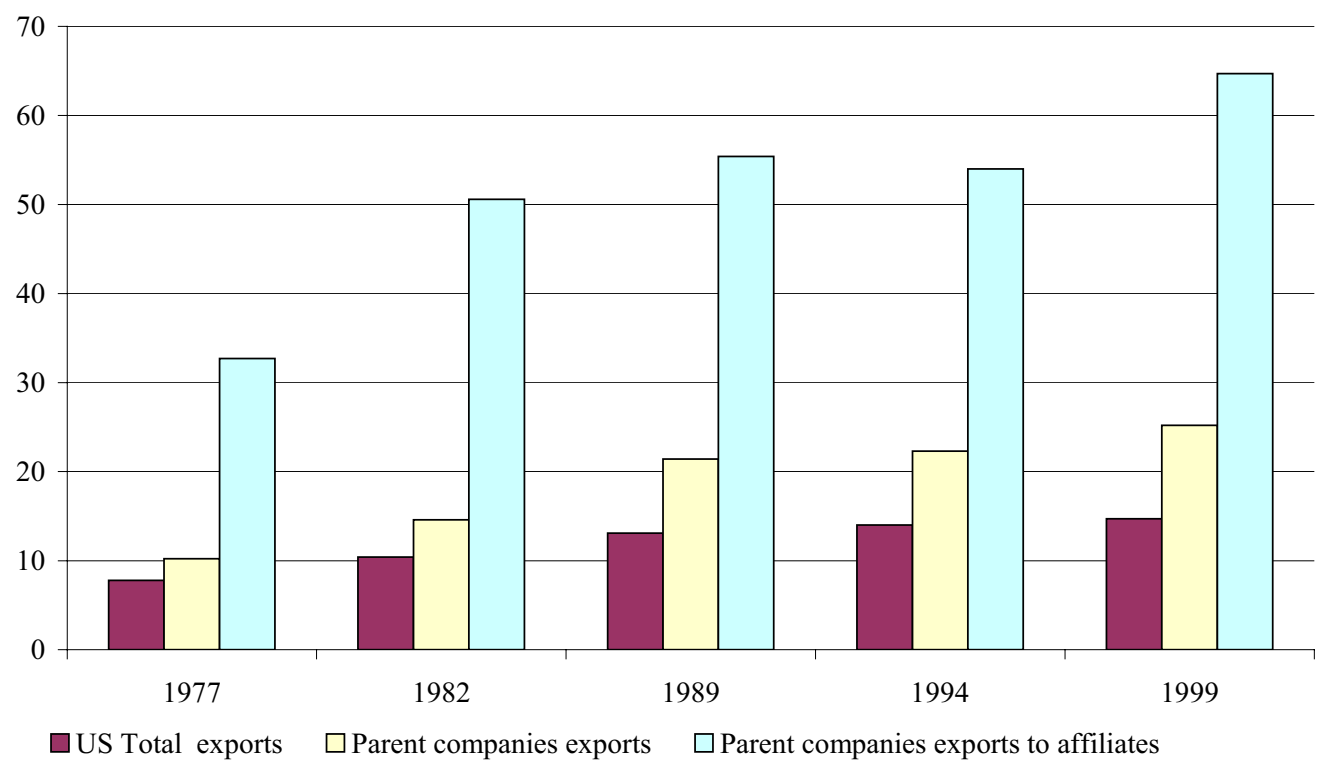

Source: Borga and Zeile (2004).

In short, there is a growing concentration in exporting activities. The number of large exporting firms is diminishing while their share of exports is increasing. Large companies tend to control the distribution of their products while their exports for further processing is increasing very fast. 


\subsection{French multinationals}

French exports in the manufacturing sector are less concentrated than US ones: large French companies with more than 500 employees account for $71 \%$ of French exports against $85 \%$ for the US (Tables $1 \& 2$ ). The geographic and economic (similar levels of development) proximity of most export markets for French companies may explain why small companies are more active in the export business than US ones.

Table 2: French and US exporting companies, 1999

Billions of US \$

\begin{tabular}{llrr}
\hline & & France & USA \\
\hline & Total Economy & & \\
3 & Total exports & 335.6 & 695.8 \\
& Manufacturing Companies & & \\
9 & Exporting companies, units & 16,962 & 65,795 \\
10 & Exports of companies & 201.0 & 407.2 \\
11 & Share in total exports (10/3) & $60 \%$ & $69.6 \%$ \\
12 & Exports to related Companies & 116.7 & 159.0 \\
13 & Share of intra-firm (12/10) & $58 \%$ & $39.0 \%$ \\
14 & Large exporting companies, units & 951 & 3,509 \\
15 & Exports by large companies & 143.2 & 349.7 \\
16 & Share of large companies in total exports (15/10) & $71 \%$ & $85.5 \%$ \\
17 & Of which to related parties & 90.5 & 148.8 \\
18 & Share of large companies in total exports to related companies $(17 / 12)$ & $78 \%$ & $93.6 \%$ \\
19 & Share of intra-firm exports in large companies total exports (17/15) & $63 \%$ & $42.6 \%$ \\
20 & Share of large companies intra-firm exports in total manuf. exports & $45 \%$ & $36.5 \%$ \\
& (17/10) & & \\
\hline
\end{tabular}

Source: France: Business surveys for the manufacturing sector and food industry; Ministry of Industry, SESSI intra-group trade survey; INSEE National accounts; USA: op.cit. Table 1.

As a result, French large parent companies carve in a smaller share of intra-firm trade than their US counterparts: only $78 \%$ of total exports compared to $93 \%$ for the US. But the share of intra-firm trade in French large companies exports is much higher than in the US case (63\% against $42 \%$ ). Hence, large US firms export more to non-affiliates. Last, the share of intra-firm trade for further processing in large manufacturing companies' total exports is similar in both countries (between 25\% and 28\%) as shown in Figure 2. 
Figure 2: US and French large firms exports, 1999

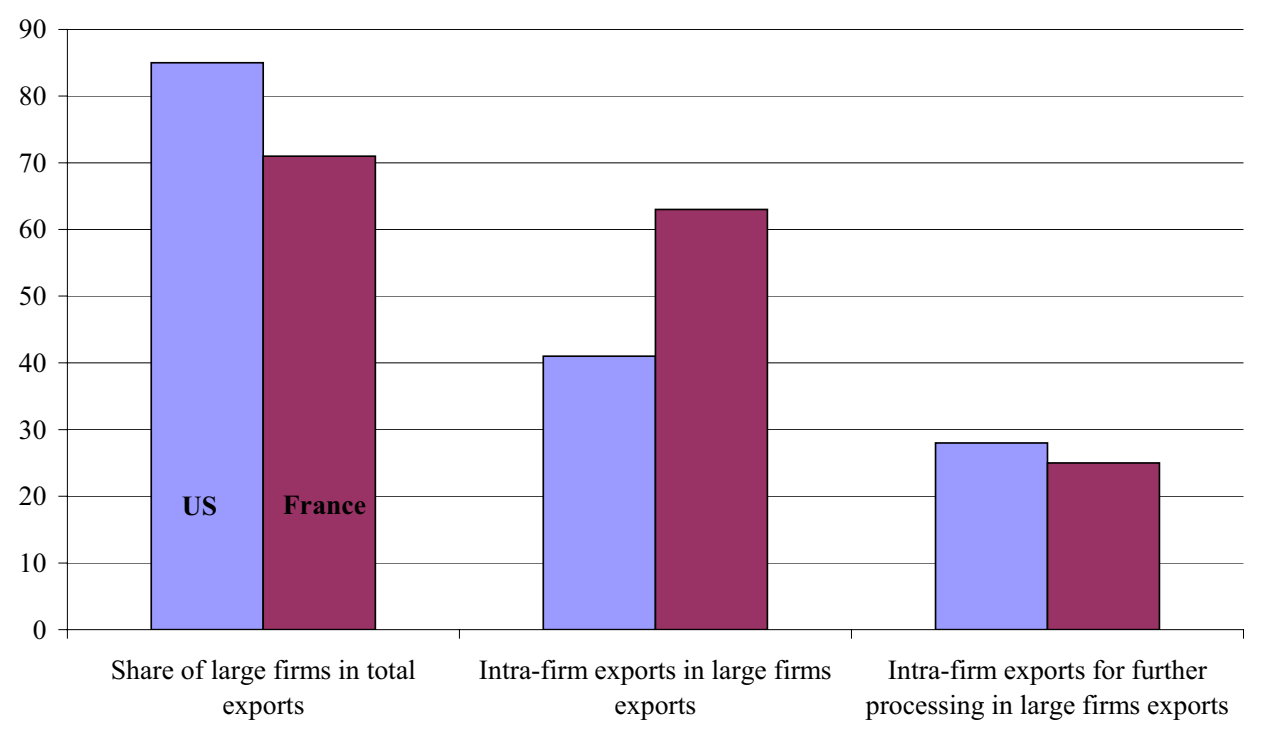

Source: BEA for the US; Ministry of Industry, SESSI for France.

To conclude, intra-firm trade appears to be relatively constant over time but it seems to be evolving somewhat towards the fragmentation of production processes.

\section{A MODEL OF VERTICAL INTEGRATION}

\subsection{Literature overview}

A prolific literature has provided many reasons for the internalisation of production by MNCs. In turn, many studies have dealt with MNCs behaviour concerning the substitutability or complementarity between FDI and intra-firm exports. For example, Helpman et alii (2003) find that productivity and firm-level heterogeneity are important determinants of both exports and horizontal FDI in the foreign markets. Moreover, transport costs and tariffs tend to reduce exports relative to FDI. Fairly similarly, Grossman et alii (2003) show that firms strategies are influenced by the relative size of fixed costs for FDI, in the context of significant transportation costs. Costly transport of intermediate goods leads multinationals to produce in multiple locations. 
Vertical integration has been recently explained by focusing on property rights, transaction costs or the incentive system (Spencer, 2005), and further, on search and information costs (Grossman and Helpman, 2002; Swenson, 2005). Another promising avenue of research is related to the organisation of firms according to their distance to the world technology frontier. In Acemoglu et alii 's model (2002), being far from the frontier drives firms to keeping a vertical integration; conversely, being close to the frontier leads them to commit to innovation activities, by outsourcing to high income countries.

In the outsourcing approach that does not necessarily involve MNCs, the vertical specialisation is defined as the use of imported inputs in the production of goods meant for exports (Hummels et al., 1999). In the paper by Hummels et alii, input-output data show that a small decrease in trade costs (tariffs and transportation costs) can involve a large increase in vertical production networks. Swenson (2004) finds that an increase in production costs in the host country entails a decrease in the fragmentation of production processes. More specifically, when the production cost of one competitor country rises, production is displaced to a host country with lower production costs. HMS (2005) show that the increasing share of imported intermediates by affiliates can be explained by decreasing wage and trade costs, giving prevalence to vertical production networks.

In research papers on MNCs using French surveys, Mucchielli et al. (2000) point to a strong complementarity between intra-firm trade and FDI, but substitutability between inter-firm trade and FDI. With the same data, Raspiller and Sillard (2004) investigate the trade-off between affiliating and subcontracting. Technology and advertising are correlated with intra-firm trade. Furthermore, quality and trademarks tend to boost the profits achieved by MNCs, outweighing the fixed costs borne by MNCs when they set up affiliates.

\subsection{The empirical model}

We rely on the approach developed by HMS (2005) to trace the determinants of intra-firm trade for French multinationals. The variation in imported inputs for further processing by foreign affiliates from their French parents is explained by the change in trade and labour costs facing the affiliates. The imported inputs in the affiliate total costs are measured by the share of imported inputs for further processing in the affiliate's turnover, $\mathrm{S}_{\mathrm{ipcm}}$, where $\mathrm{i}$ stands for the sector, $\mathrm{p}$ the parent company, $\mathrm{c}$ the country, and $\mathrm{m}$ the imported input for further processing.

The estimated equation is:

$$
\begin{aligned}
\mathrm{S}_{\mathrm{ipcm}}=\alpha_{\mathrm{ip}}+\beta_{1} \ln \text { Wage }_{\mathrm{c}} & +\beta_{2} \ln \mathrm{LP}_{\mathrm{c}}+\beta_{3} \ln \text { Distance }_{\mathrm{c}}+\beta_{4} \ln (1-\text { Corp Tax Rate } \\
& = \\
+ & \beta_{5} \ln \left(1+\text { Tariff }_{\mathrm{cm}}\right)+\gamma X_{p c}+e_{i p c m}
\end{aligned}
$$


All exogenous variables are in logarithms. Wage stands for the wage per employee, and $L P$ is value added per employee in the manufacturing sector of the host country. It was adjusted in order to remove multicolinearity. ${ }^{4}$ Distance is a proxy for transportation costs and measures the distance separating France from the host country. The specification also includes the top statutory corporate tax rate of the host country, the tariffs levied by the host country of the affiliate on the imported products, and a vector $\mathrm{X}$ of miscellaneous variables. $\mathrm{X}$ includes three dummies: one indicating if the country hosts an export processing zone, another one if the parent company subcontracts to a non-related party and one for EU membership. The use of a dummy for partnership with a non-related party may allow to check the research assumptions formulated above. Furthermore, $\mathrm{X}$ includes an index of economic freedom and an indicator of the market potential in the host country. The market potential variable indicates if MNCs exports of intermediate products to their affiliates are associated with market penetration of the host country area.

All the variables are detailed in Appendix 1.

This specification also includes a set of parent $\mathrm{x}$ industry dummy variables, $\alpha_{i p}$, to control for unobserved heterogeneity coming from the specific pattern within each 2-digit sector and the particular relationship between a given parent company and the industry of its affiliates. For example, knowing the identity of the parent company helps control for specific services provided by the parent firm to its affiliates, such as patents, trademarks, market analysis, etc. Moreover, the price of intermediate inputs being proxied by parent by industry dummies together with distance and tariffs, allows to take into account transfer pricing. Once the intermediate input price determinants are controlled for, a positive coefficient on corporate tax rate then indicates profit shifting practices (see HMS, 2005 for a discussion).

\section{DATA SOURCES}

\subsection{Surveys of parent companies and affiliates}

The intra-group international trade flows survey conducted by the SESSI, Ministry of Industry, in 2000 for the reference year 1999 concerns bilateral trade flows above $€ 1$ million (or half this amount for flows directed to emerging countries) of manufacturing or wholesale trade groups located in France. The survey covers 8,239 industrial firms.

\footnotetext{
To do so, the productivity variable was orthogonalised by regressing it on wages. The initial equation is updated by using the residual vector since it is then independent from wages.

5

The trade-off between affiliating or subcontracting may imply search costs minimisation or may be motivated by technology and advertising efforts (see Swenson, 2005;Raspiller and Sillard, 2004), op.cit.

${ }^{6}$ A firm may include one or several establishments and is registered in a sector according to its main activity code. An international industrial group controls at least $50 \%$ of the assets of one firm abroad.
} 
Of the surveyed firms, 4,305 have answered and have provided a workable questionnaire. These firms belong to 2,136 groups, representing only $52 \%$ of the number of firms surveyed but they cover $82 \%$ of trade flows of all firms surveyed.

299,752 observations are related to trade (export or import) from a firm located in France toward a firm located in another country for a given product, itemised in the harmonised system of the United Nations, at the 4 digit level (HS4).

Out of the 4,305 firms, 3,361 firms trade with their affiliates abroad; hence, 944 do not perform any trade with affiliates abroad, but they may contract partnerships, in order to secure inputs or strike a technological alliance, or they can also sell at arm's length. 486 firms have, indeed, a close relationship with another firm established abroad (partnerships); 3,927 firms do carry out sales with non-affiliates.

For our own needs, we select only exports from the firms established in France towards their affiliates and retain exports meant for further processing or finishing purposes. Intragroup trade on account of investment or exports of finished goods to an affiliate are then excluded. We then end up with a file including 23,814 observations and 174 host countries. 186 product categories in the HS4 classification are listed.

Unfortunately, this database does not provide any information on the affiliates themselves. Another survey, conducted and released by the French Ministry of Economy and Finance, is therefore used. It includes the turnover and employment of 5,548 affiliates related to multinational firms located in France, identified by their firm number.

The snag is that the parent companies database does not provide information on the affiliates the exports are directed to, and symmetrically, the affiliates' database does not tell which products are received from the parent company. So, it is decided to add up turnovers or employees of all the affiliates of a country pertaining to the same parent company, i.e. turn them into a single super-affiliate which imports products for further processing from the parent company in the host country. The merge between both databases (parent companies and affiliates) results in a total of 2,762 observations. ${ }^{8} 70$ countries and 230 parent companies are listed. On average, exports sum up to about twelve flows by each parent company and about three flows are directed to a single affiliate.

\footnotetext{
${ }^{7}$ In this second database, affiliates held with an equity stake of more than $50 \%$ and with 20 employees at least on their payroll are shortlisted.

8 In contrast with HMS whose sample is made up of 4,285 majority-owned foreign affiliates of US MNCs in 1994, each exported product sent by the US MNC being received by one different foreign affiliate in the host country, our sample includes a HS4 set of distinct products exported by one French MNC to its unique affiliate abroad.
} 
Table 3: French MNC export flows, by host country, 1999

\begin{tabular}{ccc}
\hline & Nbr & Exports (\%) \\
\hline Total & observations & Exp \\
EUROPE & 2,762 & 100 \\
$\quad$ EU15 & $\mathbf{2 , 1 1 3}$ & $\mathbf{7 7}$ \\
New Member States (10 countries) & 1,884 & 68 \\
Other Europe & 96 & 3 \\
AMERICA & 133 & 5 \\
$\quad$ North America & $\mathbf{3 1 1}$ & $\mathbf{1 1}$ \\
$\quad$ Central and South America & 123 & 4 \\
AFRICA & 188 & 7 \\
$\quad$ Sub-Saharian & $\mathbf{2 1 9}$ & $\mathbf{8}$ \\
$\quad$ North Africa & 90 & 3 \\
ASIA & 129 & 5 \\
$\quad$ Japan & $\mathbf{1 0 5}$ & $\mathbf{4}$ \\
South-East Asia & 22 & 1 \\
Other Asia & 67 & 2 \\
OCEANIA & 16 & 1 \\
Developed countries & $\mathbf{1 4}$ & $\mathbf{1}$ \\
Developing countries & $\mathbf{1 , 9 2 5}$ & $\mathbf{7 0}$ \\
\end{tabular}

Source: Ministry of Industry, SESSI intra-group trade survey.

$80 \%$ of exports in our database are directed to Europe or to developed countries (Table 3 ). The remaining 20\% go to developing countries in America, Africa and Asia. The cut-off point between developed and developing countries is the PPP GDP per capita of Spain (see Section 4.3). The main sample is essentially made up of export flows of intermediate goods, and to a lesser extent, of equipment goods and car parts exported for further processing (Table 4). As a matter of fact, $64 \%$ of intermediate goods are directed to foreign affiliates in developing countries and $47 \%$ in the developed ones, whereas the proportion of both cars and equipment goods exported to the affiliates amounts to $26 \%$ in the developing countries and $47 \%$ in the developed ones.

Another interesting point is that $40 \%$ of exports of parent companies to their affiliates are matched by imports, whatever the product considered, $22 \%$ of these back-flows match the HS2 (two-digit) classification and $13 \%$ of these flows correspond to the product that was primarily exported to the affiliate in the HS4 classification. 
Table 4: French MNC export flows by industry, 1999

\begin{tabular}{lcccccc}
\hline & \multicolumn{2}{c}{ TOTAL } & \multicolumn{2}{c}{ Developed } & \multicolumn{2}{c}{ Developing } \\
\cline { 2 - 7 } & Obs. & $\begin{array}{c}\text { Exports } \\
(\%)\end{array}$ & Obs. & $\begin{array}{c}\text { Exports } \\
(\%)\end{array}$ & Obs. & $\begin{array}{c}\text { Exports } \\
(\%)\end{array}$ \\
\hline Total & $\mathbf{2 , 7 6 2}$ & $\mathbf{1 0 0}$ & $\mathbf{1 , 9 2 5}$ & $\mathbf{1 0 0}$ & $\mathbf{8 3 7}$ & $\mathbf{1 0 0}$ \\
$\quad$ Food & 39 & 1 & 25 & 1 & 14 & 1 \\
Consumer goods & 233 & 6 & 143 & 5 & 90 & 7 \\
Equipment goods & 639 & 44 & 419 & 47 & 210 & 26 \\
$\quad$ Of which cars & 103 & 25 & 63 & 26 & 40 & 17 \\
Intermediate goods & 1,794 & 49 & 1,311 & 47 & 483 & 64 \\
Energy & 34 & 0 & 14 & 0 & 20 & 2 \\
Business services+other & 25 & 0 & 13 & 0 & 10 & 0 \\
\hline
\end{tabular}

Note: obs.: observations; in units. Intermediate products for further processing have been gathered in broad product categories using the French Nomenclature Economique de Synthèse (NES) classification.

Source: Ministry of Industry, SESSI intra-group trade survey.

\subsection{Comparability with the US study}

The greatest comparability with the BEA survey on US affiliates is sought for, but differences related to the nature of the databases emerge. Our data deal with the year 1999, while the US study covers 1994. During this five-year period, there has been a marked evolution in the behaviour of multinational firms. Nonetheless, the geographical locations of France and the US and their membership to regional clusters can make a substantial difference as to their export strategy to their affiliates and remain constant over time.

Beyond these time considerations, the main gap to be considered between both databases lies in the absence of data about affiliates in our core database, so depriving us of valuable information to typify them. This feature has some impact on our econometric strategy. By contrast, much more information is given in the BEA survey on US affiliates, feeding the econometric tests with controls on the affiliate side.

\section{ECONOMETRIC TESTS}

\subsection{A common strategy that does not work}

Table 5 reports the baseline HMS estimates and Table 6 shows the results obtained with our data. Our first results are clearly inconclusive. In the regression, we do not have any regressor at the affiliate level, only the regressand is. This is a major drawback because we then do not control for the firm's importance or size which might drive our estimates away. Accordingly, our observations are weighted by the number of employees for each superaffiliate. Furthermore, as most of our variables are at country-level, the disturbance term is allowed to be correlated within each country (Moulton, 1990). No coefficient appears to be significantly different from zero at the 5\% level. Our interpretation here is that these poor estimates might be driven by statistical artefacts. 
Table 5: Results in Hanson, Mataloni, Slaughter (2005)

Preferred specification

\begin{tabular}{lcccc}
\hline \multicolumn{1}{c}{ Parameters } & Coefficients & \multicolumn{3}{c}{ Standard errors } \\
\hline More skilled wages & 0.027 & 0.010 & $* * *$ & $(+)$ \\
Less skilled wages & -0.046 & 0.011 & $* * *$ & $(-)$ \\
Capital rental rate & 0.001 & 0.005 & & \\
$(1+$ trade costs) & -0.333 & 0.089 & $* * *$ & $(-)$ \\
(1-corporate tax rate) & 0.044 & 0.028 & $*$ & $(+)$ \\
Output & -0.007 & 0.004 & $*$ & $(-)$ \\
Adjacent to the US & 0.126 & 0.014 & $* * *$ & $(+)$ \\
Export processing zone & 0.043 & 0.015 & $* * *$ & $(+)$ \\
Nontariff barriers & 0.021 & 0.012 & $*$ & $(+)$ \\
Host market size & -0.043 & 0.010 & $* * *$ & $(-)$ \\
Economic freedom & -0.037 & 0.009 & $* * *$ & $(-)$ \\
\hline
\end{tabular}

Note: $(* * *),(* *),(*)$ represent respectively significance at the $1 \%, 5 \%$ and $10 \%$ level. The dependent variable is the share of imports for further processing from the US in total affiliate costs. Wages are compensation divided by employment. The more skilled wages are measured as wages per employee recorded in the country's chemical, electronics, and electrical machinery industries whereas the unskilled wages are measured as the annual salary per worker in a country's apparel sector. Capital rental rate and output are affiliate-level regressors. Trade costs are tariffs and transportation costs. Statutory corporate income tax rates measure maximum marginal tax rates facing affiliates. Host market size is a measure of market potential (national GDP plus a distance-weighted sum of GDPs in neighbouring countries). Economic freedom is an index of various variables compiled by the Heritage foundation and the Wall Street Journal. All variables are in logarithms except the three dummies that are adjacent to the US, Export processing zone and Non tariff barriers. The regression includes a set of 777 parent-by-industry dummies.

\subsection{An alternative regressand}

The first issue here is on our endogenous variable. A closer look at the ratio points to a possible culprit, namely, measurement error. Out of the 2,762 rows of our primary sample, more than 700 display a ratio of imports to turnover greater than unity. There is hardly an economic explanation for such a phenomenon. Then, the reliability of our dataset has to be questioned. The most convenient way around this problem is to look for valid instruments for our affiliates' turnover. Then, the fitted values obtained with this strategy will be freed from measurement errors. But due to the lack of data availability at the affiliate level, the list of possible instruments appears to be extremely limited. In fact, the MoF database, besides the turnover, only includes data on the number of employees for each affiliate. We then assume that the labour productivity of French affiliates, $a$, defined as their revenues per worker $\left(\mathrm{RPW}_{\mathrm{api}}\right)$ may be proxied by the labour productivity of their French parents, $p$, $\left(\mathrm{RPW}_{\mathrm{pi}}\right)$ at the affiliate HS2 industry level $i$. For each industry, a single equation is estimated while assuming that the error terms are correlated across industries (SUR method):

$$
\mathrm{RPW}_{\mathrm{api}}=\alpha_{\mathrm{i}}+\beta_{\mathrm{i}}^{*} \mathrm{RPW}_{\mathrm{pi}}+\mathrm{e}_{\mathrm{api}}
$$


The average adjusted $\mathrm{R}^{2}$ amounts to $35 \%$ and the coefficients $\beta_{\mathrm{i}}$ are significant at the $5 \%$ level, except miscellaneous industries and wholesale trade. This statistic may seem a bit weak, but considering the strong correlation between labour productivity of affiliates and of parent companies in the US ${ }^{9}$ (Appendix 2), this corroborates our view that the affiliates' turnover variable cannot be trusted. Indeed, a large part of its variability can be seen as a measurement error.

\section{Table 6: Preliminary results}

\begin{tabular}{lcc}
\hline & Developed & Developing \\
& $(1)$ & $(2)$ \\
\hline Wage & -0.5832 & 0.0164 \\
Labour productivity & $(1.0719)$ & $(0.0113)$ \\
Distance & 1.2024 & $-0.0182^{*}$ \\
& $(0.8098)$ & $(0.0094)$ \\
(1-Corp tax rate) & 0.8089 & 0.0016 \\
& $(1.2614)$ & $(0.0095)$ \\
(1+Tariffs) & -9.6971 & 0.0664 \\
& $(10.9079)$ & $(0.0574)$ \\
EU15 & -2.5362 & 0.0556 \\
& $(4.4117)$ & $(0.0724)$ \\
EPZ & -1.7844 & -0.0010 \\
Special relationship & $(3.0075)$ & $(0.0241)$ \\
& $2.6018 *$ & 0.0055 \\
Economic freedom & $(1.5180)$ & $(0.0127)$ \\
& 1.6772 & $-0.0767 * *$ \\
Market Potential & $(1.2025)$ & $(0.0365)$ \\
& 1.4517 & -0.0351 \\
Observations & $(6.1551)$ & $(0.0482)$ \\
Control Type & 1.0694 & -0.0013 \\
& $(1.6042)$ & $(0.0190)$ \\
\hline
\end{tabular}

Note: For each specification, the regressand is the ratio of imports to turnover. The control type line indicates how our set of dummy variables is specified. A stands for the 'parent-industry' control. Results are estimated by GEE, assuming that the error term is correlated within each country. Each observation is weighted by the inverse of the affiliate's number of employees. Robust standard errors are in parentheses. $(* * *),(* *),(*)$ represent respectively significance at the $1 \%, 5 \%$ and $10 \%$ level.

Our new turnover variable is then obtained by multiplying the fitted productivity by the number of employees of each firm. But as it can be seen in Table 6, column 2, correcting only for measurement errors does not make our results look any better. Various alternative methods such as iteratively reweighted least squares have been tried without success.

As a matter of fact, in the US case, the labour productivity of the affiliate is quite correlated with the one of its parent. The productivity of all US affiliates amounts to $85 \%$ of that achieved by their parent companies in the manufacturing sector (Appendix 2). 


\subsection{Cluster Analysis}

In HMS (2005) p. 666, it can be read: "We assume that U.S parent firms have previously chosen in which countries to locate affiliates. The remaining decision is over which production activities affiliates should perform". Unlike HMS, we do believe that the analysis of production activities requires, in the first place, to account for unobservable characteristics inherited from location decisions. Hence, production decisions are assumed to differ according to the type of the host country, either developing or developed. By implementing a cluster analysis based on the Euclidean distance between each couple of observations, on the whole set of controls used so far, we obtain two main clusters (reported in Table 7) for which the cumulated proportion of variance explained by their eigenvalues is around $87 \%$. The first one gathers affiliates located in low-wage developing countries ( 828 observations), the second one is made up of developed countries ( 1,818 observations). The opposition between developed and developing through this clustering is unchallenging. It is then decided to split up our sample in two by considering Spain PPP GDP per capita as the cut-off point between developed and developing countries, since it matches our cluster mapping.

Table 7: Cluster Analysis Computed sample means (in logarithms)

\begin{tabular}{lccc}
\hline & Class1 & Class2 & Full Sample \\
\hline Number of countries & 51 & 18 & 69 \\
Number of observations & 828 & 1,818 & 2,646 \\
Wage & 8.09 & 10.28 & 8.63 \\
Labour Productivity & 9.44 & 11.07 & 9.87 \\
Distance & 8.50 & 6.95 & 8.13 \\
Corporate tax rate & -0.38 & -0.40 & -0.38 \\
Tariffs & 0.09 & 0.004 & 0.07 \\
EU15 & 0.04 & 0.71 & 0.21 \\
Developed & 0.06 & 1 & 0.28 \\
EPZ & 0.84 & 0.47 & 0.75 \\
Special relationship & 0.01 & 0.10 & 0.03 \\
Economic freedom & 1.08 & 0.73 & 0.99 \\
Market Potential & -9.39 & -8.12 & -9.09 \\
$S_{\text {aipcm }}$ & 0.08 & 0.06 & 0.07 \\
\hline
\end{tabular}

Note: the classification was obtained by the agglomerative hierarchical clustering procedure at the country level. For the definition of classes, see Section 4.3.

10 If the estimated pattern on alternative sub-samples differs noticeably in terms of the direction of the slope, estimating the equation on the full sample will result in a less precise estimator, that would besides be overweighted by the largest sub-sample. 


\subsection{Preferred specification}

Our preferred regression is then run on either the "developed" or the "developing" countries' sub-sample (Table 8). The results are very close to those obtained with the clustering procedure. We then control for the sector of each affiliate and correct for heteroscedasticity. As stated above, we weight our observations by the number of employees of each affiliate and the disturbance terms are allowed to be correlated within each country. By doing so, the results obtained are clearly improved in terms of significance. Interestingly, the industry breakdown does not differ whatever the sample considered. Apparently, there is no real export flow specialisation according to the geographical location (by Nace- 2 digits).

Table 8: Preferred specification

\begin{tabular}{lcccc}
\hline & \multicolumn{2}{c}{ Developed countries } & \multicolumn{2}{c}{ Developing countries } \\
\cline { 2 - 5 } & $(1)$ & $(2)$ & $(3)$ & $(4)$ \\
\hline Wage & $0.0829^{* * *}$ & $0.0844^{* * *}$ & -0.0021 & $-0.0139^{* *}$ \\
Labour productivity & $(0.0224)$ & $(0.0205)$ & $(0.0106)$ & $(0.0076)$ \\
& $0.3174^{* * *}$ & $0.1849^{* * *}$ & $-0.0262^{* * *}$ & $-0.0320^{* * *}$ \\
Distance & $(0.0454)$ & $(0.0579)$ & $(0.0075)$ & $(0.0063)$ \\
& $-0.0555^{* * *}$ & $-0.0324 * *$ & $-0.0205^{*}$ & -0.0012 \\
(1-Corptaxrate) & $(0.0186)$ & $(0.0130)$ & $(0.0121)$ & $(0.0094)$ \\
& -0.0173 & 0.0404 & 0.0619 & -0.0631 \\
(1+Tariffs) & $(0.1058)$ & $(0.0661)$ & $(0.0603)$ & $(0.0922)$ \\
& $-1.2388^{*}$ & $-1.7266^{* * *}$ & $0.1784 * * *$ & 0.0133 \\
EU15 & $(0.7061)$ & $(0.5741)$ & $(0.0364)$ & $(0.0447)$ \\
& -0.0850 & -0.0420 & -0.0105 & -0.0201 \\
EPZ & $(0.0593)$ & $(0.0348)$ & $(0.0127)$ & $(0.140)$ \\
& 0.0160 & 0.0178 & 0.0030 & 0.0213 \\
Special relationship & $(0.0152)$ & $(0.0106)$ & $(0.0175)$ & $(0.0166)$ \\
& 0.0052 & $-0.0731^{* * *}$ & $-0.1576^{* * *}$ & $-0.0590^{* * *}$ \\
Economic freedom & $(0.0146)$ & $(0.0098)$ & $(0.0558)$ & $(0.0214)$ \\
& $0.2205^{* *}$ & 0.0437 & $-0.1568^{* * *}$ & $-0.1324 * * *$ \\
Market Potential & $(0.0968)$ & $(0.0479)$ & $(0.0451)$ & $(0.0459)$ \\
& $-0.0900^{* * *}$ & $-0.0692^{* * *}$ & $-0.0300^{* *}$ & -0.0126 \\
Observations & $(0.0250)$ & $(0.0211)$ & $(0.0138)$ & $(0.0112)$ \\
Control Type & 1,847 & 1,847 & 766 & 766 \\
\hline
\end{tabular}

Note: for each specification, the regressand is the ratio of imports to turnover. Columns (1) and (2) show results from the 'developed countries' sample and (3) and (4) from the 'developing countries' one. The control type line indicates how our set of dummy variables is specified. ' $A$ ' stands for the 'parent-industry' control and ' $B$ ' for the 'industry' control. Economic freedom must be read by inverting signs. Results are estimated by GEE, assuming that the error term is correlated within each country. Each observation is weighted by the inverse of the affiliate's number of employees. Robust standard errors are in parentheses. $(* * *),\left(^{* *}\right),(*)$ represent respectively significance at the $1 \%, 5 \%$ and $10 \%$ level. 


\subsection{Robustness check}

As a robustness check, it is decided to render our endogenous variable discrete. We compute the median of our ratio for each sub-sample and create a dummy. The probit estimation we use determines which regressors matter for the share of exports in turnover to be higher than the median. Even if the loss of valuable information might be important, this method is well adapted for dealing with measurement errors. For convergence of the estimator, the number of dummy variables has to be limited. Following HMS, it is chosen to specify only the industry control rather than the parent-industry cross effects. As shown in Table 9, the probit estimates match pretty well the results obtained with our linear method in terms of signs and significance levels.

Table 9: Probit regression

\begin{tabular}{lcc}
\hline & Developed & Developing \\
& $(1)$ & $(2)$ \\
\hline Wage & $0.9582^{* * *}$ & -0.1548 \\
Labour productivity & $(0.2837)$ & $(0.1004)$ \\
& $2.1134 * * *$ & $-0.1910^{* *}$ \\
Distance & $(0.5679)$ & $(0.0993)$ \\
& $-0.3221^{* * *}$ & -0.0441 \\
(1-Corp tax rate) & $(0.1287)$ & $(0.1246)$ \\
& -0.3133 & -0.6094 \\
(1+Tariffs) & $(0.8247)$ & $(1.1235)$ \\
& 0.6406 & 0.1130 \\
EU15 & $(5.5439)$ & $(0.7853)$ \\
& 0.1121 & -0.2501 \\
EPZ & $(0.2804)$ & $(0.2310)$ \\
Special relationship & -0.0105 & -0.0853 \\
& $(0.1272)$ & $(0.2317)$ \\
Economic freedom & $-0.7752^{* * *}$ & -0.2061 \\
& $(0.1146)$ & $(0.2667)$ \\
Market Potential & $1.9872 * * *$ & $-1.7487 * * *$ \\
& $(0.5686)$ & $(0.5975)$ \\
Observations & $-0.8052^{* * *}$ & $-0.3193 *$ \\
Control Type & $(0.2427)$ & $(0.1776)$ \\
\hline
\end{tabular}

Note: for each specification, the regressand is the ratio of imports to turnover. Column (1) shows results from the 'developed countries' sample and (2) from the 'developing sample' one. The control type line indicates how our set of dummy variables is specified. 'B' stands for the 'industry' s control. Economic freedom must be read by inverting signs. The main specification is estimated by a probit after having rendered the endogenous variable discrete at its median. Each observation is weighted by the inverse of the affiliate's number of employees. Robust standard errors are in parentheses. $(* * *),(* *),(*)$ represent respectively significance at the $1 \%, 5 \%$ and $10 \%$ level. 
Another check consists in selecting only the manufacturing affiliates to run our preferred specification. The results (not reported here) are quite similar to those obtained with the whole sample.

Table 10: Re-imported and non re-imported flows

\begin{tabular}{|c|c|c|c|c|}
\hline & \multicolumn{2}{|c|}{ Re-exports to France } & \multicolumn{2}{|c|}{ Non re-exported flows } \\
\hline & $\begin{array}{l}\text { L-int. Prod } \\
\text { (1) }\end{array}$ & $\begin{array}{c}\text { K-int. Prod } \\
\text { (2) }\end{array}$ & $\begin{array}{c}\text { L-int. Prod } \\
\text { (3) }\end{array}$ & $\begin{array}{c}\text { K-int. Prod } \\
\text { (4) }\end{array}$ \\
\hline \multirow[t]{2}{*}{ Wage } & -0.0201 & $0.0309 *$ & $0.0369^{* *}$ & -0.0092 \\
\hline & $(0.0170)$ & $(0.0167)$ & $(0.0158)$ & $(0.0102)$ \\
\hline \multirow[t]{2}{*}{ Labour productivity } & $0.1126^{* *}$ & $-0.0522 * * *$ & 0.0003 & 0.0230 \\
\hline & $(0.0566)$ & $(0.0068)$ & $(0.0112)$ & $(0.0259)$ \\
\hline \multirow[t]{2}{*}{ Distance } & $-0.0420 * *$ & $0.0328 *$ & $0.0232 * *$ & -0.0105 \\
\hline & $(0.0184)$ & $(0.0196)$ & $(0.0119)$ & $(0.0273)$ \\
\hline \multirow[t]{2}{*}{ (1-Corp tax rate) } & $0.2532 * * *$ & $-0.1730^{*}$ & 0.0606 & 0.0578 \\
\hline & $(0.0643)$ & $(0.1081)$ & $(0.0842)$ & $(0.1420)$ \\
\hline \multirow[t]{2}{*}{$(1+$ Tariffs $)$} & $0.3705^{* * *}$ & 0.1586 & 0.0302 & 0.1249 \\
\hline & $(0.0851)$ & $(0.2891)$ & $(0.1039)$ & $(0.1234)$ \\
\hline \multirow[t]{2}{*}{ EU15 } & 0.0234 & $0.0865^{* * *}$ & -0.0478 & 0.0109 \\
\hline & $(0.0316)$ & $(0.0252)$ & $(0.0438)$ & $(0.0299)$ \\
\hline \multirow[t]{2}{*}{ EPZ } & $0.0865^{* *}$ & 0.0066 & -0.0173 & $0.0299 *$ \\
\hline & $(0.0372)$ & $(0.0231)$ & $(0.0185)$ & $(0.0169)$ \\
\hline \multirow[t]{2}{*}{ Special relationship } & -0.0504 & 0.0145 & $-0.0364 *$ & $-0.1400^{* *}$ \\
\hline & $(0.0333)$ & $(0.0107)$ & $(0.0196)$ & $(0.0586)$ \\
\hline \multirow[t]{2}{*}{ Economic freedom } & $-0.3489 * * *$ & $0.1764 * * *$ & $0.1227 * *$ & $-0.1918 * * *$ \\
\hline & $(0.0559)$ & $(0.0567)$ & $(0.0641)$ & $(0.0658)$ \\
\hline \multirow[t]{2}{*}{ Market Potential } & $-0.0981 * * *$ & -0.0296 & $0.0391 * *$ & -0.0269 \\
\hline & $(0.0352)$ & $(0.0404)$ & $(0.0203)$ & $(0.0588)$ \\
\hline Observations & 570 & 453 & 778 & 807 \\
\hline Control Type & A & A & A & A \\
\hline
\end{tabular}

The regressand is the ratio of imports to turnover. Column (1) and (2) show results for the re-importation flows sample and columns (3) and (4) those that are exported back to France. Each sample is respectively split up according to the labour (columns 1 and 3) and capital intensity (columns 2 and 4) of imported intermediate products (see Appendix 1). The control type line indicates how our set of dummy variables is specified. 'A' stands for the 'parent-industry' control. Economic freedom must be read by inverting signs. Results are estimated by GEE, assuming that the error term is correlated within each county. Each observation is weighted by the inverse of the affiliate's number of employees. Robust standard errors are in parentheses. $(* * *),(* *),\left(^{*}\right)$ represent respectively significance at the $1 \%, 5 \%$ and $10 \%$ level. 
A further test is then carried out. We estimate the same equation on the restricted sample of affiliates which export their production back to their French parents. In this sample, 75\% are European countries and 52\% are German, Italian, Spanish, and British. In parallel, the regression is run by selecting only the intermediates import flows that are not exported back to France. Moreover, we separate out labour-intensive intermediate products from capitalintensive ones. The double distinction between products exported back or not to France / labour or capital-intensive inputs can document how affiliates operate, by taking advantage, for example, of their market size to sell their labour- or capital-intensive production to local markets. Results show that the coefficient on market potential is only significant for labourintensive products, negative when products are exported back to France and positive when products are not exported back. Likewise, the same dichotomy for unit wage costs, i.e. the difference in logarithms of wages per employee and labour productivity, is observed: the coefficient is negative when considering exported-back-labour-intensive products (column 1), and positive for those that are not exported back (column 3). The horizontal dimension of production networks can thus be specified at least for the labour-intensive products (see Table 10, column 3, and Appendix 1).

\section{RESULTS}

As shown by the results in Table 8, the observed strategies of French MNCs within each sample (developed versus developing) differ greatly, pointing to a specific pattern according to the affiliates' location.

- Robust estimates are drawn for the coefficient on wages. Wages per employee impact positively on the import to turnover ratio for the developed countries' sample, and negatively for the developing countries one. One interpretation is that wages per employee mirror the average skill intensity of jobs in a country: the higher wages are, the higher the average skill-content of jobs in the country. The less-skilled labour intensive affiliates are located in countries where wage costs are relatively lower, and conversely for the developed countries. This fits the vertical integration view and the HMS findings. The cross-price elasticity of imported-input demand to wages stands around 1.9 for the developed countries and around -0.2 for the developing ones. ${ }^{11}$ The flow of imported inputs seems to be much more influenced by wage variation for the affiliates in the developed countries that rely extensively on more-skilled labour. For developing countries, the limited magnitude of the elasticity indicates that other factors appear also to be crucial in explaining its variation.

- Interestingly, labour productivity matters a lot in explaining patterns of intra-firm trade. In developed countries, labour productivity looms large in multinationals' decisions to export intermediate products to their affiliates as shown by the positive and significant coefficient for this variable, whatever the control set. In contrast, in developing economies, the use of labour, a relatively abundant and cheap factor, trims

\footnotetext{
${ }^{11}$ The cross-price elasticity of imported-input demand to wage and transportation costs, stemming from the HMS' model, has been calculated as described in Appendix 3.
} 
down labour productivity to negative figures. Furthermore, real unit wages, the difference in the logarithms of wages per employee and labour productivity, corroborate the dichotomy between developed and developing economies. This difference, for the developed countries, results into a negative coefficient on unit wage costs, labour productivity being in excess of wages per employee. Conversely, in the developing countries, unit wage costs are rather low but positive, pointing to a lesser importance of cost-competitiveness for parent companies as a motive to export intermediate products towards their affiliates.

- As to distance, a proxy for freight costs, the impact is negative for both developed and developing countries. These results match those of HMS. Transport costs have a negative impact on imported input flows, and this supports the vertical production scheme of MNCs. Interestingly, the elasticity relative to distance for the developing economies is about the same as the wage elasticity (about -0.3 ) whereas it is -1.2 for developed economies. The response to a $1 \%$ variation in transport costs is less important in absolute terms than the same $1 \%$ variation in wages of developed countries. It is difficult to compare these elasticities with those obtained in HMS as trade costs are bundled together (freight costs and tariffs).

- Coefficients on tariffs are quite affected by zero tariffs inside the EU-15 for both samples, developed and developing countries: the strong presence of EU-15 countries does not allow the real effect of tariffs on exports of intermediates to be disentangled in the developed countries' sample but at least it is negative, meeting HMS' results. For the developing countries' sample, only when controlling for the identity of the parent company, is the impact strong and positive. One possible explanation is that multinational firms can be offered tariff exemptions by host countries in order to attract them there. For instance, in the automotive sector, the screening of firms by host countries has been acknowledged as a common practice.

- No real evidence of tax rates effects can be found. The corporate tax rate is not significant at all. The presence of an Economic Processing Zone which grants tax breaks, or transfer pricing may explain the absence of any significance in both samples.

- The economic freedom index is significant, and its impact is negative in the developed countries and positive in the developing ones. The negative coefficient (to be read upside-down, i.e. a positive impact) means that an improvement in economic conditions leads to higher exports of parent companies to their related parties. The coefficient on economic freedom happens to be positive in the developed countries, but the variance of the economic freedom index in these countries is rather low. In the context of developed economies, this variable seems to capture other unobserved factors.

- Partnership trade (special relationship), i.e. trade performed by the MNCs with nonrelated subcontractors, and intra-firm trade appear to be substitutes. In the textile, apparel and wearing sector, for instance, multinationals rely mainly on subcontractors rather than on intra-firm trade. Partnership trade occurs more often with European 
countries: in our sample, $15 \%$ of European countries vs. $7 \%$ of non European countries perform such a trade. Additional tests show that, after removing the EU-15 dummy, the partnership variable is positive and significant with the parent-industry control. ${ }^{12}$ In certain circumstances, affiliate operations can be completed by a back-up of production by non-related parties if need be, or else, production can be separately carried out taking advantage of specific assets in each location.

- The market potential variable, which indicates what the distribution strategy of the parent company is, turns out to be negative and significant in both samples. This supports the idea that affiliates do not sell their processed production in their own markets to take advantage of the market size.

As a matter of fact, $40 \%$ of export flows are matched by imports of parent companies from their affiliates. Hence, parent companies may export intermediate products and import assembled goods. The export flow of intermediate inputs is then supposed to have precedence over the import flow from the affiliate. Regressions are run then on two samples according to the breakdown between flows that are exported back to France and those that are not (Table 10).

Each sample is respectively split up according to the capital to labour intensity of imported intermediate products. Vertical specialisation stands clearly off for labour-intensive products that are exported back to France (column 1), as exemplified by the negative market potential coefficient, whereas no evidence is found for capital products (column 2). According to column 1, the weaker the market size, the higher intra-firm flows in intermediate products. Now, if we turn to affiliates that do not resell their production to their parent companies, we find a positive impact of the distance, unit wage costs (the difference in the logarithms of wages per employee and labour productivity) and market potential variables for labour-intensive products, giving credit to an horizontal intra-firm specialisation pattern (column 3). For capital-intensive products, the nature of the intra-firm trade cannot really be typified (column 4). The underlying assumption we started with is maybe not relevant for this kind of goods: parent companies may, on the reverse, import capital-intensive intermediate products to be processed at home or in another area.

In short, market potential has a significant impact only for labour-intensive products in both samples: negative for the reshipped products and positive, as expected, for products that are likely to access the host country's market.

\section{CONCLUDING REMARKS}

The main objective has been to identify the determinants of intra-firm trade in intermediate inputs using French data following Hanson, Mataloni and Slaughter (2005). It has been found that wages, but also labour productivity, and trade costs have a strong impact on intra-firm flows of intermediate inputs.

12

Additional tests are not reported here but are available on request. 
The results provide strong evidence for the vertical pattern of production networks. The need to distinguish between developing and developed countries has emerged from our cluster analysis. Wage and transportation costs are lowest in the developing countries and have, as expected, a negative impact on the share of imported inputs in the affiliates' turnover. The opposite is observed for wages in the developed countries.

The responsiveness of imported-input demand to the wages of more-skilled labour is higher in our estimation than the one found by HMS (1.8 against 0.36 ). Labour productivity, and in turn lower unit wage costs, are important factors explaining French MNCs' export pattern in the developed countries, whereas in the developing countries, the attractiveness of cheap labour seems to override considerations linked to unit labour costs.

Cross-price elasticities with respect to trade costs are negative in developed countries as in HMS. In developing countries, the effect of tariffs can unveil specific advantages given to foreign firms to attract them. Freight costs have a negative impact in both samples.

Partnership has been paid special attention. Subcontracting and intra-firm trade seem to be substitutes except in the developed European countries, where some French multinationals can strike partnerships with unrelated parties in order to exploit synergies between partners owning specific assets and affiliates located in high-wage countries.

To complete the picture, the negative coefficient for the market potential variable in our preferred specification indicates that multinationals rather operate in narrow markets in both developed and developing countries. Developments were necessary to explore further the vertical and horizontal aspects of FDI related to the market size of the host-country. The double distinction between products exported back or not to France and between labourversus capital- intensive products makes it possible to highlight a global mix of vertical and horizontal FDI or at least further processing in other countries. Indeed, market access is the main objective for productions using labour-intensive intermediate products.

However, we suspect that even if the production process is vertical, the number of stages remains low. Further research could concentrate on the number of stages of production necessary to reach a final product. Intermediate input exports by parent companies to their foreign affiliates might only be refined a limited number of times, as French firms are more concentrated in sectors whose production processes are somewhat less separable: cars, basic chemicals, electrical and non-mineral products. Industries requiring a high degree of fragmentation of their production process are known to be minor industries in France (for example, electronics).

\footnotetext{
${ }^{13}$ See for a classification of industries: the Broad Economic Classification. See also for the French industry positions: Nayman and Ünal-Kesenci (2001).
} 


\section{REFERENCES}

Acemoglu, Daron, Philippe Aghion and Fabrizio Zibilotti. 2002. Vertical integration and Distance to the Frontier. NBER Working Paper 9191, September.

Bernard, Andrew B., J.Bradford Jensen and Peter K. Schott. 2005. Importers, Exporters, and Multinationals: a Portrait of Firms in the U.S. that Trade Goods. NBER Working Paper 11404, June.

Borga, Maria, William J. Zeile. 2004. International Fragmentation of Production and the Intrafirm Trade of U.S. Multinational Companies. Bureau of Economic Analysis WP 2004-02.

Brainard, Lael. 1997. An Empirical Assessment of the Proxy-Concentration Tradeoff between Multinational Sales and Trade. American Economic Review, 87(4): 520-540.

Carr, David L., James R. Markusen, and Keith E. Maskus. 2001. Estimating the Knowledge-Capital Model of the Multinational Enterprise. American Economic Review, 91(3): 693-708.

Gaulier, Guillaume, Françoise Lemoine and Deniz Ünal-Kesenci. 2005. China's Integration in East Asia: Production sharing, FDI and High-Tech Trade. CEPII Working Paper 2005-09, June.

Grossman, Gene and Elhanan Helpman. 2002. Outsourcing versus FDI in Industry Equilibrium. CEPR Discussion Paper Series 3647, May.

Grossman, Gene, Elhanan Helpman, and Adam Szeidl. 2003. Optimal Integration Strategies for the Multinational Firms. NBER Working Paper 10189, December.

Hanson, Gordon H, Raymond J. Mataloni and Matthew J. Slaughter. 2005. Vertical Production Networks in Multinational Firms. The Review of Economics and Statistics, 87(4): 664-678, November.

Hanson, Gordon H, Raymond J. Mataloni and Matthew J. Slaughter. 2001. Expansion Strategies of Multinational Firms. In D. Rodrik and S.Collins (eds) Brooking Trade Forum: 245-294.

Helpman, Elhanan, Marc J. Melitz, and Stephen R. Yeaple. 2003. Export versus FDI. NBER Working Paper 9439, January.

Hummels, David, Jun Ishii and Kei-Mu Yi. 2001. The Nature and Growth of Vertical Specialisation in World Trade. Journal of International Economics, 54 (1): 75-96. 
Liang, K.-Y, and S.L Zeger. 1986. Longitudinal Data Analysis Using Generalized Linear Models. Biometrica, 73: 13-22.

Moulton, Brent R. 1990. An Illustration of a Pitfall in Estimating the Effects of Aggregate Variables on Micro Units. The Review of Economics and Statistics, 72 (2): 334-338, May.

Mucchielli, Jean-Louis, Séverine Chédor and Isabelle Soubaya. 2000. Investissements directs à l'étranger des multinationales françaises et relations commerciales avec leurs filiales. Revue Economique, 51 (3): 747-760, May.

Mundell, Robert A. 1957. International trade and Factor Mobility. American Economic review, 57:321-335.

Nayman, Laurence and Deniz Ünal-Kesenci. 2001. The French-German Productivity Comparison Revisited: Ten Years after the German Reunification. CEPII Working Paper 2001-14, December.

Nelder, J.A, and R.W.M. Wedderburn. 1972. Generalized linear models. Journal of the Royal Statistical Society, Series A 135:370-384.

Raspiller, Sébastien and Patrick Sillard. 2004. Affiliating versus Subcontracting: the Case of Multinationals. INSEE document de travail G 2004/09, December.

Spencer, Barbara. 2005. International Outsourcing and Incomplete Contracts. NBER Working Paper 11418, June.

Swenson, Deborah. 2005. Outsourcing Price Decisions: Evidence from U.S. 9802 Imports. NBER Working Paper 11184, March.

Swenson, Deborah. 2004. Overseas Assembly and Country Sourcing Choices. NBER Working Paper 10697, August.

U.S. Bureau of Economic Analysis. 2002. US Direct Investment Abroad: Preliminary Results From the 1999 Benchmark Survey. US GPO. 


\section{APPENDIX 1: DATA SOURCES AND DEFINITIONS}

\section{Wages per employee}

HMS separate out wages in the least labour-skilled sectors from those in the more labourskilled sectors, in order to get a dummy for wages for skilled and unskilled labour. Unlike them, we prefer to use the average wage in the host country manufacturing sector. This can be a good proxy of skilled and unskilled labour, as it is used in samples involving the developed and the developing economies.

Two databases related to wages have been merged: the first one is the UNIDO database, which reports total annual wages in US dollars over annual employment for 101 countries, in the manufacturing sector.

The second one is the NBER database, which draws on the ILO "October Inquiry". Up to now, this database covers 156 countries and 161 occupations.

Freeman and Ostendoorp ${ }^{14}$ focus on the 1983-1998 period. Because many observations are missing, and in order to make for the heterogeneity of the data (gross or net wages, minimum wage or average or median wage, hourly wage rate, etc.), the authors calibrate the various statistics into a normalised wage or earnings rate. The standardised rate thus obtained through econometrics is the monthly average wage for male workers and can be compared across countries.

A merge between the UNIDO and the NBER databases has been carried out, harmonising them into a united database entailing 132 countries. National price and exchange rate fluctuations have been taken into account in order to extrapolate data.

\section{Labour productivity}

Labour productivity is value added per employee in the manufacturing sector at current prices. The series mainly come from the UNIDO and NBER databases.

\section{Tariffs}

Tariffs come from the MacMaps database (Market Access Maps) ${ }^{15}$, a bilateral and disaggregated measure of market access covering the major instruments of protection ( $\mathrm{ad}$ valorem and specific duties, tariff quotas, etc.) for the year 1999. The construction of this database results from various sources: national customs offices, TRAINS from the

${ }^{14}$

Freeman, R. B. and R. H Oostendorp (2000) 'Wages Around the World: Pay Across Occupations and Countries', NBER working paper series, $\mathrm{n}^{\circ} 8058$, December. 15

The MacMaps is a joint database run by the CEPII and the International Trade Centre (Geneva). 
UNCTAD, COMTRADE from the United Nations, the AMAD database and from the national notifications of anti-dumping procedures reported to the WTO. Here, ad valorem and specific duties equivalent tariffs have been aggregated at the HS4 level (CEPII calculations, Yvan Decreux).

\section{Transportation costs}

As a proxy, the distance series from Haveman are used. We keep distance of all countries relative to France. Alternatively, we use the distance series from CEPII that are a bit more sophisticated. The results are not changed at all for developing countries and hardly altered for the developed countries.

http://www.macalester.edu/research/economics/PAGE/HAVEMAN/Trade.Resources/Trade Data.html

http://www.cepii.fr/francgraph/bdd/distances.htm

\section{Market potential}

The market potential of each host country is estimated using the average of GDP of all countries, weighted by the inverse of the distance separating other countries from the host one (CEPII calculations, Guillaume Gaulier).

\section{Corporate income tax rates}

Like HMS (2005), we include the maximum statutary corporate tax rate facing businesses. The source of it is the World Tax Database of the University of Michigan.

\section{The Heritage Foundation Index of Economic Freedom}

The Heritage Foundation and Wall Street Journal Index of Economic Freedom is a compound of 50 variables, namely: trade policy, fiscal burden of government, government intervention in the economy, monetary policy, capital flows and foreign investment, banking and finance, wages and prices, property rights, regulation and informal market activity.

\section{Export processing zones}

As in Hanson, Mataloni \& Slaughter (2005), dummies are included for export processing zones. Information is derived from the ILO database.

\section{Purchasing Power Parity GDP}

PPP GDP is taken from the CHELEM database (CEPII). It is close to the World Bank database. The base year is 1996 . 


\section{Special relationship}

A dummy is introduced according to whether the firm, along with its intra-firm trade, has developed a special relationship with other firms abroad in the host country (technological alliance, licensing, etc.). This variable is included in the parent company survey conducted by the French Ministry of Industry (SESSI).

\section{Capital to hours ratios}

Goods above the average capital to hour ratio were assumed to be capital intensive and those below labour intensive, based on the EUKLEMS database for France in 1999 (capital stock per hour worked at 1995 prices). The list in the European NACE Rev.1 classification is as follows:

Labour intensive goods: 17, 18, 19, 20, 22, 25, 28, 29, 30, 31, 33, 35, 36;

Capital intensive goods: 15, 16, 21, 23, 24, 26, 27, 32, 34 . 


\section{APPENDIX 2:}

RELATIVE PRODUCTIVITY OF AFFILIATED COMPANIES TO US PARENTS 1999 , in \%

Manufacturing

Food

Beverages and tobacco

$\begin{array}{ll}\text { Textiles, apparel \& leather } & 72\end{array}$

$\begin{array}{ll}\text { Wood } & 77\end{array}$

$\begin{array}{ll}\text { Paper } & 77\end{array}$

$\begin{array}{ll}\text { Printing \& related support } & 67\end{array}$

Petroleum \& coal $\quad 241$

$\begin{array}{lr}\text { Chemicals } & 94\end{array}$

$\begin{array}{ll}\text { Basic chemicals } & 108\end{array}$

Resins \& synthetic rubber, fibers, \& filaments $\quad 126$

Pharmaceuticals \& medicines $\quad 86$

Soap, cleaning compounds, \& toilet preparations 62

$\begin{array}{ll}\text { Other } & 123\end{array}$

Plastics \& rubber products $\quad 80$

Non metallic mineral products $\quad 69$

Primary \& fabricated metals $\quad 86$

$\begin{array}{ll}\text { Primary metals } & 84\end{array}$

Fabricated metal products $\quad 94$

$\begin{array}{ll}\text { Machinery } & 89\end{array}$

Agriculture, construction, \& mining machinery $\quad 82$

Industrial machinery $\quad 91$

$\begin{array}{ll}\text { Other } & 96\end{array}$

$\begin{array}{ll}\text { Computers and electronic products } & 75\end{array}$

Electrical equipment, appliances, and components 48

$\begin{array}{ll}\text { Transportation equipment } & 83\end{array}$

$\begin{array}{ll}\text { Motor vehicles, bodies and trailers, and parts } & 67\end{array}$

$\begin{array}{lr}\text { Furniture and related products } & 73\end{array}$

\begin{tabular}{lr} 
Miscellaneous manufacturing & 100 \\
\hline
\end{tabular}

Source: www.bea.gov/bea/di/dilusdop.htm 


\section{APPENDIX 3: THE HMS'S EMPIRICAL MODEL}

Hanson, Slaughter and Mataloni [2005] developed an empirical specification to analyse the organisational pattern of US multinationals toward their foreign affiliates. In the model, US MNCs choose the production activities performed by their affiliates, whether it is motivated by the reduction of production costs, or rather by a facilitated access to far markets.

Let us consider a foreign affiliate with a cost function $C(w, Y) . Y$ stands for affiliate total output and $w$ is the vector of factor prices facing the affiliate. Assuming a translog function as the functional form for costs, we can write:

$\ln C=\alpha_{0}+\sum_{h=1}^{H} \alpha_{h} \ln w^{h}+\frac{1}{2} \sum_{h=1}^{H} \sum_{j=1}^{H} \gamma_{h j} \ln w^{h} \ln w^{j}+\beta_{y} \ln Y+\frac{1}{2} \beta_{y y} \ln Y^{2}+\sum_{h=1}^{H} \phi_{h y} \ln w^{h} \ln Y$

where $w^{h}$ is the price of the optimally chosen input $h=1, \ldots, H$.

We, then, take the first derivative of (A) with respect to $\ln w^{h}$. Combining the derivation properties of the translog function with the Shepard's lemma, the elasticity of total cost with respect to the price of factor $h$ is equivalent to the share of factor $h$ in total cost, denoted $s^{h}$, as $\partial \ln C / \partial \ln w^{h}=\left(\partial C / \partial w^{h}\right)\left(w^{h} / C\right)$ and $\partial C / \partial w^{h}$ is the demand of input $h$. We can then write for $h=1, \ldots, H$

$$
s^{h}=\alpha_{h}+\sum_{j=1}^{H} \gamma_{h j} \ln w^{j}+\phi_{h y} \ln Y
$$

As the study focuses on intra-firm trade, HMS consider for their empirical investigations, $s^{m}$, which is the cost share of inputs for further processing in total costs facing the affiliate. Thus, they assume that affiliates with a higher $s^{m}$ are more specialised in the processing of intermediate inputs exported by their parents.

We use this definition of $s^{m}$ to derive or estimate equation (1) in Section 2.2.

Last, let's stress how elasticities are computed. Like HMS, we do not report the cross price elasticities of our ratio $s^{m}$ to variation of the input price $h$ but calculate the cross price elasticities of demand of input $m$ to variations of the input price $h$. Thus, using the properties mentioned above, it is straightforward to find that the cross price elasticity of demand between input $m$ and a variable input $h$ is given by:

$$
P E D_{m h}=\frac{\gamma_{m h}+s^{m} s^{h}}{s^{m}}
$$




\section{LIST OF WORKING PAPERS RELEASED BY CEPII ${ }^{16}$}

No

2006-17 Import Prices, Variety and the Extensive Margin of Trade

2006-16 The Long Term Growth Prospects of the World Economy: Horizon 2050

2006-15 Economic Integration in Asia: Bilateral Free Trade Agreements Versus Asian Single Market

2006-14 Foreign Direct Investment in China: Reward or Remedy?

2006-13 Short-Term Fiscal Spillovers in a Monetary Union

2006-12 Can Firms' Location Decisions Counteract the Balassa-Samuelson Effect?

2006-11 Who's Afraid of Tax Competition? Harmless Tax Competition from the New European Member States

2006-10 A Quantitative Assessment of the Outcome of the Doha Development Agenda

2006-09 Disparities in Pension Financing in Europe: Economic and Financial Consequences

2006-08 Base de données CHELEM-BAL du CEPII

2006-07 Deindustrialisation and the Fear of Relocations in the Industry

2006-06 A Dynamic Perspective for the Reform of the Stability and Gowth Pact

2006-05 China's Emergence and the Reorganisation of Trade Flows in Asia

2006-04 Who Pays China's Bank Restructuring Bill?
Authors

G. Gaulier \& I. Méjean

S. Poncet

M. H. Bchir $\&$ M. Fouquin

O. Havrylchyk $\&$ S. Poncet

A. Bénassy-Quéré

I. Méjean

A. Lahrèche-Révil

Y. Decreux \& L. Fontagné

J. Château \& X. Chojnicki

H. Boumellassa \& D. Ünal-Kesenci

H. Boulhol \& L. Fontagné

C. Deubner

G. Gaulier, F. Lemoine \& D. Ünal-Kesenci G. Ma

16

Working papers are circulated free of charge as far as stocks are available; thank you to send your request to CEPII, Sylvie Hurion, 9, rue Georges-Pitard, 75015 Paris, or by fax : (33) 0153685504 or by e-mail Hurion@cepii.fr. Also available on: \www.cepii.fr. Working papers with* are out of print. They can nevertheless be consulted and downloaded from this website.

${ }^{16}$ Les documents de travail sont diffusés gratuitement sur demande dans la mesure des stocks disponibles. Merci d'adresser votre demande au CEPII, Sylvie Hurion, 9, rue Georges-Pitard, 75015 Paris, ou par fax : (33) 0153685504 ou par e-mail Hurion@cepii.fr. Egalement disponibles sur: Ilwww.cepii.fr. Les documents de travail comportant * sont épuisés. Ils sont toutefois consultable sur le web CEPII. 
2006-03 Structural Determinants of the Exchange-Rate PassThrough

2006-02 Exchange-Rate Pass-Through at the Product Level

2006-01 Je t'aime, moi non plus : Bilateral Opinions and International Trade

2005-23 World Trade Competitiveness: A Disaggregated View by Shift-Share Analysis

2005-22 Chômage et réformes du marché du travail au Japon

2005-21 Profitability of Foreign and Domestic Banks in Central and Eastern Europe: Does the Mode of Entry Matter?

2005-20 ECB Governance in an Enlarged Eurozone

2005-19 What Are EU Trade Preferences Worth for SubSaharan Africa and Other Developing Countries?

2005-18 Binding Overhang and Tariff-Cutting Formulas

2005-17 International Trade and Income Distribution: Reconsidering the Evidence

2005-16 China and the Relationship between the Oil Price and the Dollar

2005-15 Consequences of Alternative Formulas for Agricultural Tariff Cuts

2005-14 Is Erosion of Tariff Preferences a Serious Concern?

2005-13 The Consequences of Agricultural Trade Liberalization for Developing Countries: Distinguishing Between Genuine Benefits and False Hopes

2005-12 From Bound Duties to Actual Protection: Industrial Liberalisation in the Doha Round

2005-11 Impact de l'ouverture financière sur les inégalités internes dans les pays émergents
G. Gaulier,

A. Lahrèche-Révil

\& I. Méjean

G. Gaulier,

A. Lahrèche-Révil \& I. Méjean

A.C. Disdier \& T. Mayer

A. Cheptea, G. Gaulier \& S. Zignago

E. Dourille-Feer

O. Havrylchyk \& E. Jurzyk

A. Bénassy-Quéré \& E. Turkisch

F. Candau \& S. Jean

M.H. Bchir, S. Jean \& D. Laborde

I. Bensidoun, S. Jean \& A. Sztulman

A. Bénassy-Quéré, V. Mignon \& A. Penot

S. Jean, D. Laborde \& W. Martin

A. Bouët, L. Fontagné \& S. Jean

J.C. Bureau, S. Jean A. Matthews

M.H. Bchir, L. Fontagné \& S. Jean

A. Bénassy-Quéré \& V. Salins 


\section{CEPII \\ DOCUMENTS DE TRAVAIL / WORKING PAPERS}

Si vous souhaitez recevoir des Documents de travail, merci de remplir le coupon-réponse ci-joint et de le retourner à :

Should you wish to receive copies of the CEPII's Working papers, just fill the reply card and return it to:

Sylvie HURION - Publications

CEPII - 9, rue Georges-Pitard - 75740 Paris - Fax : (33) 1.53.68.55.04

sylvie.hurion@cepii.fr

M./Mme / Mr./Mrs

Nom-Prénom / Name-First name

Titre / Title .

Service / Department.....

Organisme / Organisation

Adresse / Address.

Ville \& CP / City \& post code.

Pays / Country. Tél.

Your e-mail

Désire recevoir les Document de travail du CEPII $\mathrm{n}^{\circ}$ :

Wish to receive the CEPII's Working Papers No:

Souhaite être placé sur la liste de diffusion permanente (pour les bibliothèques)

Wish to be placed on the standing mailing list (for Libraries). 